\title{
Modeling Habitat for Marbled Murrelets on the Siuslaw National Forest, Oregon, Using Lidar Data
}

Open-File Report 2018-1035 



\section{Modeling Habitat for Marbled Murrelets on the Siuslaw National Forest, Oregon, Using Lidar Data}

By Joan C. Hagar, Ramiro Aragon Perez, Patricia Haggerty, and Jeff P. Hollenbeck

Open-File Report 2018-1035

U.S. Department of the Interior

U.S. Geological Survey 


\section{U.S. Department of the Interior \\ RYAN K. ZINKE, Secretary}

\section{U.S. Geological Survey \\ William H. Werkheiser, Deputy Director \\ exercising the authority of the Director}

U.S. Geological Survey, Reston, Virginia: 2018

For more information on the USGS-the Federal source for science about the Earth, its natural and living resources, natural hazards, and the environment-visit https://www.usgs.gov/ or call 1-888-ASK-USGS.

For an overview of USGS information products, including maps, imagery, and publications, visit https:/store.usgs.gov.

Any use of trade, firm, or product names is for descriptive purposes only and does not imply endorsement by the U.S. Government.

Although this information product, for the most part, is in the public domain, it also may contain copyrighted materials as noted in the text. Permission to reproduce copyrighted items must be secured from the copyright owner.

Suggested citation:

Hagar, J.C., Perez, R.A., Haggerty, P., and Hollenbeck, J.P., 2018, Modeling habitat for Marbled Murrelets on the Siuslaw National Forest, Oregon, using lidar data: U.S. Geological Survey Open-File Report 2018-1035, 21 p., https://doi.org/10.3133/ofr20181035.

ISSN 2331-1258 (online) 


\section{Contents}

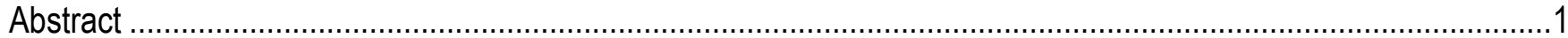

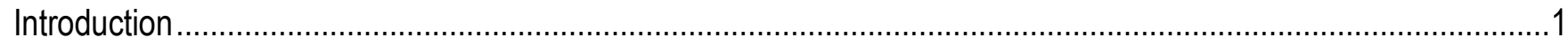

Objectives

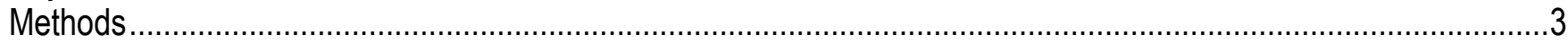

Study Area

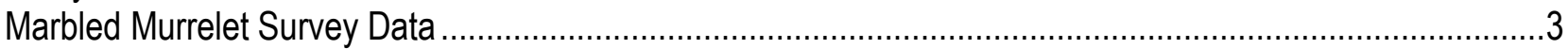

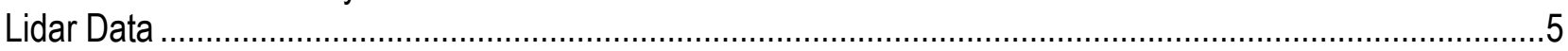

Model Testing and Development ...................................................................................................

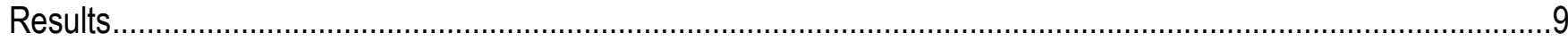

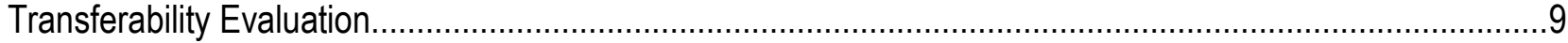

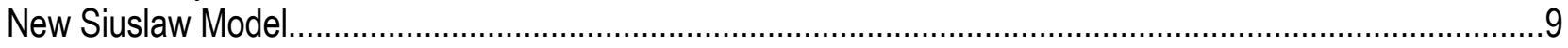

Comparison of New Siuslaw Model to Transferred Models .....................................................................

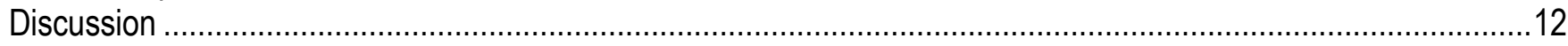

Evaluation of Model Performance ..................................................................................................13

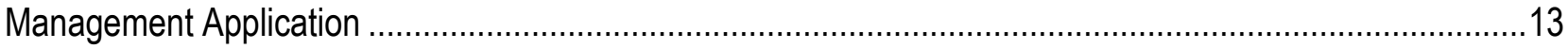

Acknowledgments

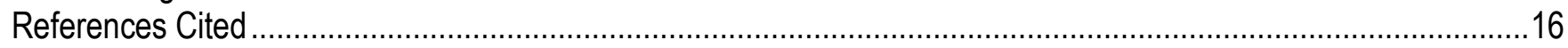

Appendix 1. Summary of Lidar Collections for Western Oregon ...................................................................18

Appendix 2. Summary of Final and Candidate Habitat Models for Marbled Murrelet in the Siuslaw

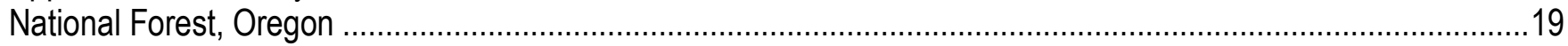

Appendix 3. Boxplots of Variables used to Develop Marbled Murrelet Habitat Model Comparing Means

and Distributions of Values between Coos Bay area and Siuslaw National Forest, Oregon.

\section{Figures}

Figure 1. Areas in western Oregon where a Marbled Murrelet habitat model was developed (Coos Bay BLM District), and where transferability of habitat model was tested (Siuslaw National Forest)

Figure 2. Predicted probability of occupancy for nesting Marbled Murrelets in the Siuslaw National Forest, Oregon, generated from lidar-derived covariates specified by a habitat model developed in the Coos Bay BLM District and transferred to the Siuslaw NF with coefficients derived from local data

Figure 3. Predicted probability of occupancy for nesting Marbled Murrelets in the Siuslaw National Forest, Oregon, generated from a habitat model trained on locally acquired (Siuslaw NF) lidar-derived variables quantifying forest structure. 


\section{Tables}

Table 1. Definition of variables used in model of Marbled Murrelet nesting habitat in the Siuslaw

National Forest, Oregon

Table 2. List of the nine candidate models used for discriminating between stands occupied by nesting

Marbled Murrelets and unoccupied stands in the Siuslaw National Forest, Oregon

Table 3. Comparison of predictive performance measures for models of Marbled Murrelet habitat in the

Siuslaw National Forest, Oregon.....

Table 4. Comparison of results of leave-one-out cross-validation for models of Marbled Murrelet occupancy in the Siuslaw National Forest, Oregon

Table 5. Results of selection of best model from among nine candidate models developed to discriminate stands occupied by Marbled Murrelets and unoccupied stands in the Siuslaw National Forest, Oregon.

Table 6. Variable descriptions and coefficients, with standard errors (SE) and significance levels, for a model of Marbled Murrelet occupancy developed with lidar-derived variables for the Siuslaw National

Forest, Oregon

\section{Conversion Factors}

U.S. customary units to International System of Units

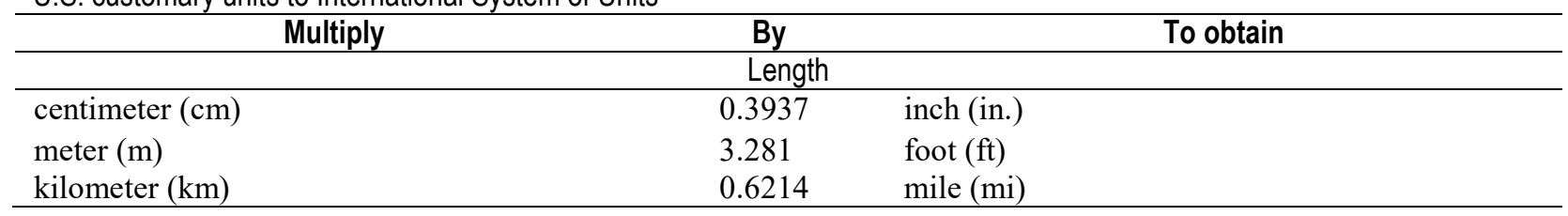

\section{Abbreviations}

$\begin{array}{ll}\text { AIC } & \text { Akaike's Information Criterion } \\ \text { AUC } & \text { area under the curve } \\ \text { BLM } & \text { U.S. Bureau of Land Management } \\ \text { CCR } & \text { correct classification rate } \\ \text { COOS } & \text { Coos Bay habitat model } \\ \text { CRR } & \text { Canopy Relief Ratio } \\ \text { HCC } & \text { Harvest: Clearcut } \\ \text { logLik } & \text { LogLikelihood } \\ \text { LOOCV } & \text { Leave One Out Cross Validation } \\ \text { NF } & \text { National Forest } \\ \text { NPP } & \text { Negative Predictive Power } \\ \text { ODF } & \text { Oregon Department of Forestry } \\ \text { OLC } & \text { Oregon LiDAR Consortium } \\ \text { PPP } & \text { Positive Predictive Power } \\ \text { ROC } & \text { receiver-operating curve } \\ \text { USDA } & \text { U.S. Department of Agriculture } \\ \text { USFWS } & \text { U.S. Fish and Wildlife Service } \\ \text { USGS } & \text { U.S. Geological Survey } \\ \text { VEGE } & \text { Base vegetation layer } \\ & \end{array}$




\title{
Modeling Habitat for Marbled Murrelets on the Siuslaw National Forest, Oregon, Using Lidar Data
}

\author{
By Joan C. Hagar, Ramiro Aragon, Patricia Haggerty, and Jeff P. Hollenbeck
}

\begin{abstract}
Habitat models using lidar-derived variables that quantify fine-scale variation in vegetation structure can improve the accuracy of occupancy estimates for canopy-dwelling species over models that use variables derived from other remote sensing techniques. However, the ability of models developed at such a fine spatial scale to maintain accuracy at regional or larger spatial scales has not been tested. We tested the transferability of a lidar-based habitat model for the threatened Marbled Murrelet (Brachyramphus marmoratus) between two management districts within a larger regional conservation zone in coastal western Oregon. We compared the performance of the transferred model against models developed with data from the application location. The transferred model had good discrimination $(\mathrm{AUC}=0.73)$ at the application location, and model performance was further improved by fitting the original model with coefficients from the application location dataset $(\mathrm{AUC}=0.79)$. However, the model selection procedure indicated that neither of these transferred models were considered competitive with a model trained on local data. The new model trained on data from the application location resulted in the selection of a slightly different set of lidar metrics from the original model, but both transferred and locally trained models consistently indicated positive relationships between the probability of occupancy and lidar measures of canopy structural complexity. We conclude that while the locally trained model had superior performance for local application, the transferred model could reasonably be applied to the entire conservation zone.
\end{abstract}

\section{Introduction}

Accurate and reliable wildlife habitat models are important for predicting species distributions to identify priority areas for conservation and restoration, as well as to guide survey efforts. Development of such models for species that inhabit the canopy of mature forests can be especially challenging because of the difficulties of discerning and measuring the relevant features at an appropriate spatial scale in complexly structured, 3-dimensional space. Light detection and ranging (lidar) is an emerging remote-sensing tool that can provide fine-scale data describing vertical complexity of vegetation, offering a promising application for improving characterization of forest structure at a sub-meter scale of resolution to inform habitat models for landscape scale applications. 
We successfully tested the utility of lidar-derived variables to accurately identify suitable nesting habitat for the Marbled Murrelet (Brachyramphus marmoratus) on the Coos Bay District of the Bureau of Land Management (BLM; Hagar and others, 2014). Our work showed that incorporating lidar-derived variables into habitat models can more accurately represent habitat for species like the Marbled Murrelet that are highly influenced by canopy structure. We determined that models with lidar-derived variables improved accuracy of habitat occupancy estimates for the Marbled Murrelet over models that use variables derived from other remote sensing techniques.

The transferability of habitat models developed for a species from one location to another can be limited when the range of values of environmental conditions differs significantly between locations (Latif and others, 2016). Although vegetation structure often is an important influence on species occurrence, especially for forest-dwelling species (MacArthur and MacArthur, 1961), environmental gradients interacting at multiple spatial scales may alter a species' relationship to finescale structure across its geographic range (Guisan and Thuiller, 2005). Therefore, although a model using variables that quantify fine-scale variation in vegetation structure may reliably predict local distribution of a species, the ability of such models to maintain accuracy at regional or larger spatial scales has not been tested. Given its capability for measuring fine-scale structure, lidar may be used most appropriately and efficiently to develop accurate models for local application, as opposed to models that are applicable over large areas, but are so general as to be uninformative for local management. A single, generally applicable model, however, would facilitate coordination of management for species of concern across jurisdictions. In particular, having a single habitat model for Marbled Murrelet Conservation Zone 3, one of six conservation zones designated in the recovery plan for the threatened Marbled Murrelet (U.S. Fish and Wildlife Service, 1997), would facilitate assessment of progress toward meeting recovery plan goals. Conservation Zone 3 includes the Coos Bay District BLM and Elliot State Forest, for which a murrelet habitat model has been developed (Hagar and others, 2014), in addition to the Siuslaw National Forest along the northern Oregon coast, which is currently lacking a fine resolution habitat model for murrelets. To evaluate the applicability of the Coos Bay Marbled Murrelet habitat model beyond the area where it was developed, we tested it against alternative habitat models developed with forest structural data and Murrelet survey data from another area within Conservation Zone 3, the Siuslaw National Forest.

\section{Objectives}

The goal of this project was to develop models that can be used to accurately map Murrelet occupancy probability, facilitating the identification and monitoring of critical nesting habitat on the Siuslaw National Forest and throughout Conservation Zone 3. The specific objectives were to:

1. Evaluate fit of Murrelet habitat model developed in Coos Bay region to data from existing Marbled Murrelet surveys and already acquired lidar data from the central Oregon Coast region.

2. Independently develop a Murrelet habitat model that is specifically applicable to the central Oregon Coast region using data from existing Marbled Murrelet surveys and lidar data from the central Oregon Coast region.

3. Compare performance of each of the models to assess which is the best predictive tool to guide habitat management for the Marbled Murrelet on the Siuslaw National Forest. 


\section{Methods}

\section{Study Area}

The study area primarily encompassed forestlands managed by the Siuslaw National Forest in the north-central Oregon Coast Ranges. Most of the Siuslaw National Forest is located north of the Coos Bay BLM District, where the first lidar-derived habitat model for murrelets was developed (Hagar and others, 2014), although some overlap between the two modeled regions occurs in the central Coast Ranges (fig. 1). Bordered on the east by the Willamette Valley and the west by the Pacific Ocean, the Siuslaw National Forest is managed under the Northwest Forest Plan (U.S. Department of Agriculture (USDA) and U.S. Department of the Interior, 1994), and comprises a significant part of Marbled Murrelet Conservation Zone 3 (U.S. Fish and Wildlife Service, 1997). As stated in the recovery plan (U.S. Fish and Wildlife Service, 1997), maintenance of suitable and occupied Marbled Murrelet nesting habitat in this region is an essential component for the stabilization and recovery of the Marbled Murrelet.

\section{Marbled Murrelet Survey Data}

We used murrelet stand-occupancy data from surveys done in the Siuslaw National Forest in the 1990s using standardized survey protocols established by the Pacific Seabird Group (Evans Mack and others, 2003). Survey sites were not randomly selected because the protocol requires that all potential suitable sites be surveyed prior to forest management projects that are likely to affect nesting habitat. Thus, all the sites used in our analysis were considered potential murrelet habitat. We did not explicitly incorporate estimates of detectability in classifying occupancy status of survey sites because surveys completed according to Pacific Seabird Group protocols should result in a greater than (>) 95 percent correct classification of site occupancy status (that is, "occupied," "presence," or "probable absence"; Evans Mack and others, 2003, p.14). For model development, we included only "intensive" surveys (not random road surveys), and excluded sites classified as "presence" because of the lack of sufficient evidence of nesting. Precise locations of murrelet nest trees cannot be determined from these surveys, so we followed the recommendation of the Pacific Seabird Group protocol to classify the entire survey site as occupied if sub-canopy behaviors were observed at any station for a given site represented by multiple stations (Evans Mack and others, 2003).

We followed similar procedures to those used by Hagar and others (2014) to classify forest stands as "occupied" or "probable absence." We used the Siuslaw National Forest Base Vegetation layer (VEGE) to identify the stand(s) that were the focus of murrelet surveys and assigned the occupancy code derived from the highest level of observation, and to identify stands that were surveyed with no detections. 


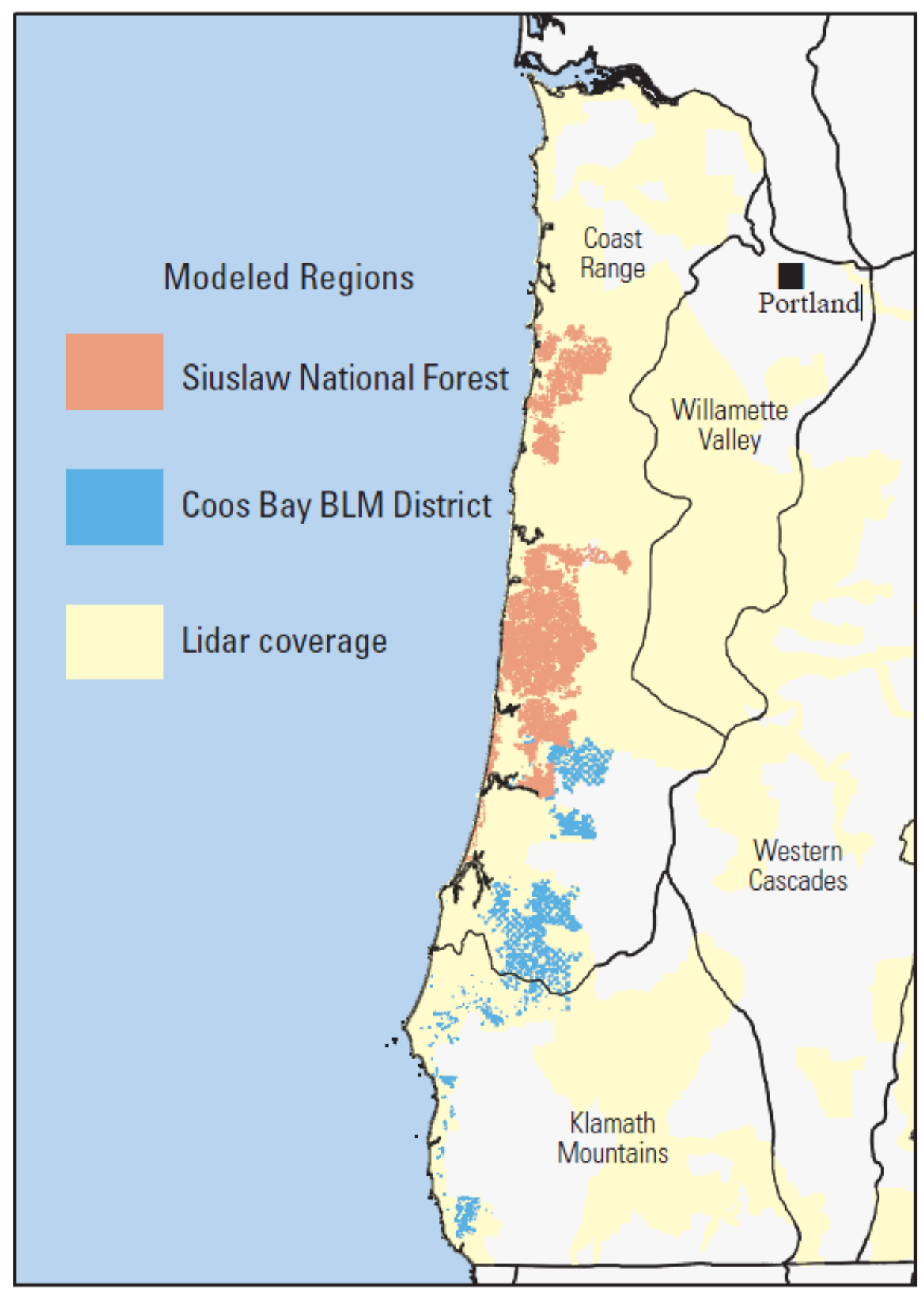

Figure 1. Areas in western Oregon where a Marbled Murrelet habitat model was developed (Coos Bay BLM District), and where transferability of habitat model was tested (Siuslaw National Forest). 
Much of the murrelet survey data were collected more than a decade prior to the data from which we derived explanatory environmental variables. Even though changes in the amount of older forest on the Siuslaw National Forest have been small since implementation of the Northwest Forest Plan in the mid-1990s (Davis and others, 2015), we used a GIS and aerial imagery from 2009 and 2014 to visually inspect every site classified as "occupied" or "probable absence" for evidence of tree harvest since murrelet surveys that would have confounded our analysis. We found few cases of management or disturbance that would have caused a significant change in forest structure on the Siuslaw National Forest in the intervening years. The VEGE polygons originally were derived from aerial photography and closely matched the forest height boundaries as observed from current aerial imagery. We also consulted a layer that represents harvested areas that includes some "Year of Origin" information (Harvest: Clearcut [HCC]). In a few cases, the polygon from the VEGE layer was clearly affected by the activity in the HCC layer so the polygon was split to correspond to the HCC layer (that is, if there had been a harvest in part of the polygon).

Attributes for each polygon contained information about dominant forest species. The dates when determinations of dominant tree species were made for each polygon are unavailable, but we assumed that tree species composition has not changed since data were initially coded. We removed polygons from the VEGE data that were hardwood dominated because they did not meet the criteria for potential murrelet nesting habitat (Evans Mack and others, 2003) and were therefore not included in surveys for Marbled Murrelets in planned timber sales. However, we retained the " $\mathrm{CH}$ " class, which represents a conifer- dominated mix. A few very small 'sliver' polygons also were excluded.

The final data set of observed occupancy status consisted of 772 stands, 553 classified as occupied and 219 classified as unoccupied.

\section{Lidar Data}

Lidar data were acquired from the Oregon Department of Geology and Mineral Industries, Oregon LiDAR Consortium (OLC; appendix 1). Six lidar projects were within the extent of the Siuslaw National Forest. Dates of the collections ranged between July 2005 and October 2014 (appendix 1). One non-OLC lidar project (Yaquina/Elk Creek) was contracted through the U.S. Forest Service; however, the same vendor and used similar standards for data collection. The OLC standard for vertical accuracy is less than or equal to 9.25 centimeters (cm) root-mean-square error (RMSE), the ground spot diameter ranges from $15-40 \mathrm{~cm}$, and the average pulse density is equal to or greater than 8 points per meter $(\mathrm{m})$ and these standards were adhered to for all projects included in this analysis.

The independent variable values were obtained from $22.9 \mathrm{~m}$ pixel seamless rasters derived from the Siuslaw National Forest LiDAR point cloud data, produced using the AreaProcessor tool of the FUSION software, version 3.60+ (McGaughey, 2016). A cutoff value of $1 \mathrm{~m}$ was used to distinguish ground from vegetation points and a height of $2 \mathrm{~m}$ defined the minimum canopy boundary. Return density within six height intervals was calculated using the strata switch in FUSION, The height intervals were determined after reviewing the measured heights of a set of known Marbled Murrelet nests in the Siuslaw National Forest and on the Oregon Coast.

Summary statistics from each lidar raster of interest were calculated for every VEGE polygon included $(n=16,088)$ using a focal statistics method. 


\section{Model Testing and Development}

Test of Coos Bay Habitat Model - We evaluated the transferability of the Coos Bay habitat model (COOS) for murrelet occupancy by applying the model developed by Hagar and others (2014) to lidar and Murrelet survey data from the Siuslaw National Forest. The model with original coefficients was as follows:

$$
\begin{gathered}
\mathrm{Y}=-15.416+0.078 * \text { allcvabvmn_MAX }+0.048 * \mathrm{p} 99 \text { M }+0.068 * \mathrm{p} 10 \_\mathrm{MAX}+0.142 * \text { frstcvabvmd_STD }+ \\
1.94 * \text { elev_kurt_MIN }-0.059 * \text { dist_kilometers })
\end{gathered}
$$

Where the first five covariates are FUSION variables derived from lidar (table 1) and defined as: allcvabvmn_MAX = the stand-level maximum value of cover above the mean height; P99_MAX = the stand-level maximum value of the height of the 99th percentile of tree heights (that is, top of canopy); p10_MAX = the stand-level maximum value of the height of the 10th percentile of tree heights (that is, bottom of canopy); frstcvabvmd_STD = the standard deviation of cover above the modal canopy height (that is, a measure of variation in upper canopy cover); and elev_kurt_MIN = the stand-level minimum value of kurtosis for the distribution of canopy height (that is, an index of the number of canopy layers). DIST2COAST is a measure of the distance from the centroid of the stand to the coastline as defined in the National Hydrological Data High Resolution, and is the same as Dist_kilometers in the original Coos Bay model (Hagar and others, 2014).

We compared the predicted occupancy generated by this model, with the original coefficients trained using the COOS data, to the observed occupancy based on field observations. To measure the model performance, we calculated the receiver-operating curves (ROC) and area under the curve (AUC) (Fielding and Bell, 1997), where AUC equaling 0.5 indicates that discrimination is not better than random, and AUC equaling 1 indicates perfect discrimination. To further refine interpretation of AUC values, we followed the classification system of Pearce and Ferrier (2000), whereby values between 0.5 and 0.7 show poor discrimination, values between 0.7 and 0.9 indicate good discrimination, and values $>0.9$ denotes excellent discrimination. Additionally, we calculated a set of performance measurements including sensitivity, specificity, positive predicted power, negative

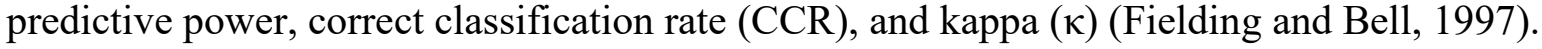
Sensitivity is the ability of the model to correctly predict occupied sites, specificity is the ability of the model to correctly predict unoccupied sites, PPP (Positive Predictive Power) measures the proportion of the occupied sites correctly predicted, NPP (Negative Predictive Power) measures the proportion of the unoccupied sites correctly predicted; CCR measures the overall ability of the model to correctly predict both occupied and unoccupied sites; and $\kappa$ is a model performance statistic for which values less than $(<) 0.4$ are considered poor, $0.4>\kappa<0.75$ are considered good, and $\kappa$ greater than or equal to $(\geq) 0.75$ excellent (Luck, 2002). To compare the performance of the COOS and SIUS models, we used the same method to determine the threshold for classifying a stand as occupied as used by Hagar and others (2014), which reflects the differential class sizes in the modeling data set (Chen and others, 2006). We calculated this threshold value as occupied/(occupied + unoccupied $)=553 / 772=0.716$. 
After evaluating the transferability of the original COOS model to SIUS, we tested another version of the model (CO_SI) that retained the complete set of original covariates, but used new coefficients derived from the SIUS data. We derived the new coefficients by fitting a logistic regression using the entire Siuslaw data set. We used Leave One Out Cross Validation (LOOCV) to validate this model. LOOCV uses a single observation from the original sample as the validation data, and the remaining observations as the training data. This process is repeated until each observation in the data set is used once as the validation data. We calculated the ROC and AUC (Fielding and Bell, 1997), as well as a set of performance measurements including, sensitivity, specificity, PPP, NPP, CCR, and $\kappa$ (Fielding and Bell, 1997) first using the predictions from the entire data set, and later using the predicted values derived from the LOOCV.

Development of New Habitat Model for Siuslaw-Finally, we developed a new set of candidate models to discriminate between occupied and unoccupied stands on the Siuslaw National Forest. This set of models incorporated new FUSION metrics that were not considered for inclusion in the COOS model (Hagar and others, 2014) but that quantified canopy structure that may be ecologically relevant to murrelets. Specifically, we derived two predictive variables reflecting the variation of vegetation density in two canopy strata (Stratum 2 and Stratum 4) that were based on the range of heights of murrelet nests in the Oregon Coast Ranges (S. K. Nelson, Oregon State University, written commun. 7 February 2017). Additional metrics considered in development of the new SIUS model that were not considered in the original COOS model were Canopy Relief Ratio (CRR) and skewness of the distribution of elevation of returns (table 1). The set of candidate models considered in the development of the SIUS model included a null model, and the CO_SI model (table 2). To facilitate comparison of the relative importance of the predictor variables in the SIUS data set, all variables in the SIUS data set were standardized by subtracting the mean (derived from all stands) and dividing by the standard deviation. Standardized variables and models incorporating standardized variables are denoted with a " $z$ " at the end of the variable name and model label.

We computed the values of the second-order Aikaike's Information Criterion (AIC), and ranked the models by AIC values, identifying the lowest $\triangle \mathrm{AIC}$ and any model within two units, which can be considered as competing models (Burham and Anderson, 2002). Additionally, we examined the models within four $\triangle \mathrm{AICc}$ units, in case one or two uninformative parameters (variables that added to a good model do not improve the fit of the model, but set it within $\Delta$ AIC less than or equal to $[\leq] 2$ of the top model) were added to a good model and set them as competing models without improving the fit of the model (Anderson, 2008; Arnold, 2010). We calculated the Akaike weight and the LogLikelihood (logLik) for each model. Akaike weight considered as the weight of evidence for the best model within a given model set. Smaller values of logLik indicate better model fits. We assessed goodness-of-fit of final models using a Hosmer-Lemeshow test (Hosmer and Lemeshow, 1980). 
Table 1. Definition of variables used in model of Marbled Murrelet nesting habitat in the Siuslaw National Forest, Oregon.

[Abbreviations: max, maximum; m, meter; min, minimum; VEGE, Siuslaw NF Base Vegetation layer]

\begin{tabular}{|c|c|c|}
\hline Source & Variable name & Description \\
\hline \multirow[t]{9}{*}{$\begin{array}{l}\text { FUSION lidar } \\
\text { utilities }\end{array}$} & allcvabmn_MAX & $\begin{array}{l}\text { Canopy cover (percent) of all returns between } 2 \mathrm{~m} \text { and mean } \\
\text { elevation for cell; maximum value }\end{array}$ \\
\hline & frstcvabvmd_STD & $\begin{array}{l}\text { Canopy cover (percent) of first returns between } 2 \mathrm{~m} \text { and mode of } \\
\text { elevation for cell; standard deviation }\end{array}$ \\
\hline & elev_P99_MAX & $\begin{array}{l}\text { Height above ground (m) for the 99th percentile of returns (that is, } \\
\text { height of the tallest trees); maximum value }\end{array}$ \\
\hline & $\overline{\text { elev_P10_MAX* }}$ & $\begin{array}{l}\text { Height above ground }(\mathrm{m}) \text { for the } 10 \text { th percentile of returns; } \\
\text { maximum value }\end{array}$ \\
\hline & elev_skew_MEAN* & Skewness of the distribution of elevation of returns; mean value \\
\hline & elev_kurt_MIN & Kurtosis of the distribution of elevation of returns; minimum value \\
\hline & $\overline{C R R \_M E A N *}$ & $\begin{array}{l}\text { Canopy Relief Ratio [(mean elevation - min elevation) } /(\max \\
\text { elevation - min elevation)]; mean value }\end{array}$ \\
\hline & $\overline{\text { STR2_STD* }}$ & $\begin{array}{l}\text { Proportion of lidar returns in the vertical stratum between } 9.87 \mathrm{~m} \\
\text { and } 36 \mathrm{~m} \text { above ground; standard deviation }\end{array}$ \\
\hline & STR4_STD & $\begin{array}{l}\text { Proportion of lidar returns in the vertical stratum between } 52.03 \mathrm{~m} \\
\text { and } 74.8 \mathrm{~m} \text { above ground; standard deviation }\end{array}$ \\
\hline $\begin{array}{l}\text { National Hydrologic } \\
\text { Dataset }\end{array}$ & DIS2COAST $^{*}$ & $\begin{array}{l}\text { Euclidean distance between VEGE polygon centroid and the Pacific } \\
\text { Ocean coastline as define by the National Hydrology Dataset high } \\
\text { resolution feature data. }\end{array}$ \\
\hline
\end{tabular}

Table 2. List of the nine candidate models used for discriminating between stands occupied by nesting Marbled Murrelets and unoccupied stands in the Siuslaw National Forest, Oregon.

[See table 1 for variable definitions]

\begin{tabular}{|l|l|}
\hline Model name & \multicolumn{1}{|c|}{ Variable } \\
\hline mod.1z & [Null] \\
\hline mod.2z & DIS2COASTz, CRR_MEANz, STR2_STDz, STR4_STDz, elev_skew_MEANz \\
\hline mod.3z & DIS2COASTz, CRR_MEANz, STR2_STDz, elev_skew_MEANz, elev_P99_MAXz \\
\hline mod.4z & DIS2COASTz, CRR_MEANz, STR2_STDz, STR4_STDz, elev_skew_MEANz, elev_P99_MAXz \\
\hline $\begin{array}{l}\text { mod.5z } \\
\text { (CO_SI } \\
\text { model })\end{array}$ & $\begin{array}{l}\text { DIS2COASTz, allcvabvmn_MAXz, elev_P99_MAXz, elev_P10_MAXz, frstcvabvmd_STDz, } \\
\text { elev_kurt_MINz }\end{array}$ \\
\hline $\begin{array}{l}\text { mod.6z } \\
\text { mod.7z }\end{array}$ & $\begin{array}{l}\text { DIS2COASTz, allcvabvmn_MAXz, elev_P99_MAXz, elev_P10_MAXz, frstcvabvmd_STDz, } \\
\text { elev_kurt_MINz, STR4_STDz } \\
\text { elev_kurt_MINz, STR2_STDz }\end{array}$ \\
\hline mod.8z & $\begin{array}{l}\text { DIS2COASTz, allcvabvmn_MAXz, elev_P99_MAXz, elev_P10_MAXz, frstcvabvmd_STDz, } \\
\text { elev_kurt_MINz, CRR_MEANz }\end{array}$ \\
\hline mod.9z & DIS2COASTz, elev_P99_MAXz \\
\hline
\end{tabular}




\section{Results}

\section{Transferability Evaluation}

The COOS model applied to the Siuslaw data with original covariates and coefficients (appendix 2) had an AUC of 0.73, but model performance was improved by fitting the COOS model with coefficients from the SIUS dataset (CO_SI model (appendix 2), table 3). Both of these versions of the transferred model are classified as having good discrimination performance (good $=$ $0.7>$ AUC $<0.9$ ) based on the interpretation scale of Pearce and Ferrier (2000), and both performed better classifying occupied stands (sensitivity) than unoccupied stands (specificity). The confusion matrix (table 4) indicates the improvement in correct classification. In particular, the CO_SI model performed markedly better than the COOS model in classifying occupied stands (specificity), CCR, NPP, and $\kappa$. The larger $\kappa$ value for the CO_SI model $(\kappa=0.68)$ indicates an improvement over the COOS model in agreement between observed and predicted values (table 3; Luck, 2002).

\section{New Siuslaw Model}

The evaluation of nine candidate models, including the CO_SI model, resulted in one model (mod.4z) that was within two $\triangle \mathrm{AIC}$ units of the top model (mod.3z; table 5). However, the difference between the top and second models was only one covariate, STR4_STDz. Further examination of both models showed that both the difference in model fit measured by $\operatorname{logLik}$ (table 5), and the difference between the residual deviances of the two models were negligible (residual deviance of $\bmod .3 \mathrm{z}=725.5$ on $766 \mathrm{df}$, residual deviance of mod.4z=725.5 on $765 \mathrm{df}$ ). Thus, STR4_STDz was considered an uninformative parameter, leaving model mod.3z as the single best model (SIUSz model, appendix 2).

\section{Comparison of New Siuslaw Model to Transferred Models}

The top model (that is, SIUSz) contained five covariates, two of which also were selected in the original COOS model: distance-to-coast and maximum canopy height (elev_P99_MAX). These covariates also had the same direction of association with probability of murrelet occupancy as in the COOS model: negative for distance-to-coast, and positive for maximum tree height. The remaining three covariates represented metrics that quantify the structural complexity of the canopy and that had not been considered during the development of the original COOS model (Hagar and others 2014). Based on performance measures (table 3 ) and cross validation (table 4), predictive performance of the CO_SI and SIUSz models were similar. 
Table 3. Comparison of predictive performance measures for models of Marbled Murrelet habitat in the Siuslaw National Forest, Oregon.

[The "COOS" model applied to the Siuslaw NF the same variables and values of coefficients as a model developed for the Coos Bay BLM District (Hagar and others, 2014) to test transferability of a model from one region to another. The CO_SI model used the same variables as the COOS model, but with coefficients parameterized with data collected at the Siuslaw National Forest. The SIUSz model (" $z$ " suffix denotes that covariates were standardized) was developed independently with data from the Siuslaw National Forest, using a model selection process that included the COOS model as a candidate]

\begin{tabular}{|c|c|c|c|}
\hline Measure & coos & CO_SI & SIUSz \\
\hline Area under the curve (AUC) & 0.73 & 0.79 & 0.78 \\
\hline Sensitivity & 0.16 & 0.74 & 0.74 \\
\hline Specificity & 0.96 & 0.65 & 0.66 \\
\hline Correct Classification Rate (CCR) & 0.39 & 0.72 & 0.72 \\
\hline Positive Predictive Power (PPP) & 0.92 & 0.84 & 0.85 \\
\hline Negative Predictive Power (NPP) & 0.31 & 0.50 & 0.50 \\
\hline Kappa (к) & 0.54 & 0.68 & 0.68 \\
\hline
\end{tabular}

Table 4. Comparison of results of leave-one-out cross-validation for models of Marbled Murrelet occupancy in the Siuslaw National Forest, Oregon.

[The COOS model used the same variables and values of coefficients as a model developed for the Coos Bay BLM District (Hagar and others, 2014) to test transferability of a model from one region to another. The CO_SI model used the same variables as the COOS model, but with coefficients parameterized with data collected on the Siuslaw NF. The SIUSz model was developed independently with data from the Siuslaw NF, using a model selection process that included the COOS model as a candidate]

\begin{tabular}{|c|c|c|c|c|c|c|c|}
\hline \multirow{3}{*}{$\begin{array}{l}\text { Observed } \\
\text { status }\end{array}$} & \multicolumn{6}{|c|}{ Predicted status } & \multirow{3}{*}{$\begin{array}{c}\text { Observed } \\
\text { Total }\end{array}$} \\
\hline & \multicolumn{2}{|c|}{ COOS model } & \multicolumn{2}{|c|}{ CO_SI model } & \multicolumn{2}{|c|}{ SIUSz model } & \\
\hline & Occupied & Unoccupied & Occupied & Unoccupied & Occupied & Unoccupied & \\
\hline Occupied & 91 & 462 & 410 & 143 & 411 & 142 & 553 \\
\hline Unoccupied & 8 & 211 & 76 & 143 & 74 & 145 & 219 \\
\hline
\end{tabular}


Table 5. Results of selection of best model from among nine candidate models developed to discriminate stands occupied by Marbled Murrelets and unoccupied stands in the Siuslaw National Forest, Oregon.

[Model "mod.5z" is the same as the model developed for Coos Bay and transferred to the Siuslaw NF (CO_SI model. See table 1 for variable definitions. AIC, Akaike's Information Criterion]

\begin{tabular}{|c|c|c|c|c|c|}
\hline Model & Variable & logLik & AIC & $\triangle \mathrm{AlC}$ & Weight \\
\hline $\bmod .3 \mathrm{z}$ & $\begin{array}{c}\text { DIS2COASTz, CRR_MEANz, STR2_STDz, } \\
\text { elev_skew_MEANz, elev_P99_MAXz }\end{array}$ & -362.752 & 737.50 & 0.000 & 0.681 \\
\hline $\bmod .4 \mathrm{z}$ & $\begin{array}{l}\text { DIS2COASTz, CRR_MEANz, STR2_STDz, } \\
\text { STR4_STDz, elev_skew_MEANz, } \\
\text { elev_P99_MAXz }\end{array}$ & -362.751 & 739.50 & 1.99 & 0.250 \\
\hline $\bmod .9 \mathrm{z}$ & DIS2COASTz, elev_P99_MAXz & -368.543 & 743.08 & 5.58 & 0.042 \\
\hline $\bmod .7 \mathrm{z}$ & $\begin{array}{l}\text { DIS2COASTz, allcvabvmn_MAXz, } \\
\text { elev_P99_MAXz, elev_P10_MAXz, } \\
\text { frstcvabvmd_STDz, elev_kurt_MINz, } \\
\text { STR2_STDz }\end{array}$ & -364.364 & 744.72 & 7.22 & 0.018 \\
\hline $\bmod .5 z^{*}$ & $\begin{array}{l}\text { DIS2COASTz, allcvabvmn_MAXz, } \\
\text { elev_P99_MAXz, elev_P10_MAXz, } \\
\text { frstcvabvmd_STDz, elev_kurt_MINz }\end{array}$ & -366.685 & 747.37 & 9.86 & 0.005 \\
\hline $\bmod .6 z$ & $\begin{array}{l}\text { DIS2COASTz, allcvabvmn_MAXz, } \\
\text { elev_P99_MAXz, elev_P10_MAXz, } \\
\text { frstcvabvmd_STDz, elev_kurt_MINz, } \\
\text { STR4_STDz }\end{array}$ & -366.589 & 749.17 & 11.67 & 0.002 \\
\hline $\bmod .8 \mathrm{z}$ & $\begin{array}{l}\text { DIS2COASTz, allcvabvmn_MAXz, } \\
\text { elev_P99_MAXz, elev_P10_MAXz, } \\
\text { frstcvabvmd_STDz, elev_kurt_MINz, } \\
\text { CRR_MEANz }\end{array}$ & -366.682 & 749.36 & 11.86 & 0.002 \\
\hline $\bmod .2 \mathrm{z}$ & $\begin{array}{l}\text { DIS2COASTz, CRR_MEANz, STR2_STDz, } \\
\text { STR4_STDz, elev_skew_MEANz }\end{array}$ & -378.330 & 768.66 & 31.15 & 0.000 \\
\hline $\bmod .1 \mathrm{z}$ & Null & -460.416 & 922.83 & 185.32 & 0.000 \\
\hline
\end{tabular}

${ }^{*} \bmod .5 \mathrm{z}$ is the transferred (CO_SI) model.

Table 6. Variable descriptions and coefficients, with standard errors (SE) and significance levels, for a model of Marbled Murrelet occupancy developed with lidar-derived variables for the Siuslaw National Forest, Oregon.

[See table 1 for variable definitions. Significant level: $* 0.01<\mathrm{P}<0.05 ; * * 0.001<\mathrm{P}<0.01 ; * * * \mathrm{P}<0.001]$

\begin{tabular}{|c|c|c|c|c|}
\hline Variable & Ecological interpretation of variable & Coefficient & SE & $\begin{array}{l}\text { Significant } \\
\text { level }\end{array}$ \\
\hline Intercept & & 0.152 & 0.127 & \\
\hline DIS2COASTz & Shortest distance to Pacific Ocean coastline & -1.269 & 0.135 & $* * *$ \\
\hline CRR_MEANz & Canopy Relief Ratio & 1.273 & 0.485 & $* *$ \\
\hline STR2_STDz & $\begin{array}{l}\text { Variation in density of cover in the vertical } \\
\text { stratum below average nesting height }\end{array}$ & -0.291 & 0.116 & $*$ \\
\hline Elev_skew_MEANz & $\begin{array}{l}\text { Skewness of the distribution of elevation of } \\
\text { returns; }\end{array}$ & 1.364 & 0.522 & $* *$ \\
\hline Elev_P99_MAXz & Maximum height of tallest trees & 1.588 & 0.188 & $* * *$ \\
\hline
\end{tabular}




\section{Discussion}

Our results indicate that the habitat model trained on local data (the SIUSz model) best discriminated stands occupied by Marbled Murrelets from unoccupied stands. Although a version of the model developed in a different region (Coos Bay) and re-fitted with local data had nearly identical performance to the locally trained model, it was ranked too low in the model selection procedure to be considered competitive. Therefore, we determined that the SIUSz model is the most appropriate of the models evaluated to be used as a guide for Marbled Murrelet habitat evaluation and management in the Siuslaw National Forest.

One potential reason for lack of transferability of habitat models is variability in the range of values of important environmental predictors between locations. Some variables that differed in both mean and range of values between the two regions did not transfer even with adjusted coefficients from Coos Bay to the Siuslaw National Forest (for example, frstcvabvmd_STD and elev_kurt_MIN; appendix 3). However, metrics quantifying canopy complexity generally performed consistently well in classifying occupancy across both regions, even though the range of variability in these metrics was sufficiently different between the two modeling regions to require re-fitting the model (appendix 3 ). Differences in the range of values of variables between modeling regions also likely explains why development of a new model trained on data from the Siuslaw (the SIUSz model) resulted in the selection of a slightly different set of lidar metrics from the original COOS model. Overall, in spite of the difference in specific lidar metrics between the two models, both models consistently indicated positive relationships between the probability of occupancy and measures of canopy structural complexity.

Spatial variability in relationships between habitat use and environmental conditions can influence transferability of habitat models. Therefore, to be useful for predicting occurrence across the geographic range of a species, habitat models need to describe ecologically meaningful habitat relationships that transcend location-specific conditions (Latif and others, 2016). Our results indicate that forest structural metrics quantified with lidar were reliably associated with occupancy by Murrelets throughout the region. The nearly identical predictive performance of the CO_SI and SIUSz models suggests their common lidar covariates describe biologically meaningful environmental relationships that generally indicate nest site suitability for the Marbled Murrelet. The consistency of these relationships across the two modeling regions is not surprising given the known association of murrelets with multi-layered, old-growth forest (Hamer and Nelson, 1995; Ralph and others, 1995; Nelson, 1997), but it suggests the likelihood that a single model using these lidar canopy metrics could be used predict suitable habitat throughout Marbled Murrelet Conservation Zone 3 (U.S. Fish and Wildlife Service, 1997).

Maximum canopy height was included as an important predictor of murrelet occupancy in both the Coos Bay BLM District and the Siuslaw National Forest. In Douglas-fir forests of the Pacific Northwest, the oldest, most dimensionally complex stands are indicated by the tallest trees. Therefore, measures of tree and canopy height frequently have been identified as among the most important explanatory variables for other species associated with late-seral forest, including northern spotted owl (Strix occidentalis caurina; Ackers and others, 2015) and red tree vole (Arborimus longicaudus; Johnston and Moskal, 2017). The unique ability of lidar to accurately measure vegetation height makes lidar metrics particularly useful for discriminating old- from young-forest habitat. However, including additional metrics to quantify canopy structure improved the ability of our models to identify the "best" nesting habitat for murrelets from mature forest stands that were all considered potential habitat. 
We believe that the incorporation of lidar metrics facilitated performance of our habitat models by refining the resolution at which we were able to quantify relationships between murrelets and the key environmental variables that govern their selection of nest sites. For example, although the association of nesting Marbled Murrelets with mature forest is well known (Nelson, 1997), factors that discriminate habitat suitability among mature forest patches with varying structure only recently have been explored (Hagar and others, 2014, this work). Our model of murrelet habitat can be used to identify habitat patches that are most likely to be highly suitable for nesting murrelets from within a landscape dominated by closed-canopy conifer forest because it is based on ecologically relevant, finescale differences in canopy structure.

\section{Evaluation of Model Performance}

The threshold for probability of occurrence we used to evaluate correct classification rates of the final model can be adjusted depending on specific management and conservation goals (Vogeler and others, 2013). However, the classification rate (specificity and sensitivity) changes with threshold value specified for occupancy probability; therefore, the threshold used should depend on management objectives. The value of 0.72 that we used represents a conservative prediction that identifies what is likely to be the highest quality habitat. We used this threshold because it correctly classified the majority of both occupied (sensitivity $>74$ percent) and unoccupied sites (specificity $>65$ percent). A lower threshold would include a wider range of potentially occupied sites and may be more appropriate for prioritizing surveys to determine nesting occupancy.

\section{Management Application}

The models we developed can be used to assess the status of murrelet habitat in Conservation Zone 3 in relation to goals specified in the recovery plan for the Marbled Murrelet, which call for "Maintenance of suitable and occupied marbled murrelet nesting habitat in the Elliott State Forest, Tillamook State Forest, Siuslaw NF, and Bureau of Land Management-administered forests ..." (U.S. Fish and Wildlife Service, 1997: p. 127). Maps of probability of occupancy throughout the Siuslaw National Forest generated from both the transferred CO_SI and the locally-derived SIUSz model were similar (figs. 2 and 3). This suggests that while the SIUSz model is considered the best model for application within the Siuslaw National Forest, the CO_SI model could be reasonably be applied to the entire Conservation Zone 3. Based on our results indicating the ability of the lidar metrics in our models to predict murrelet habitat reliably, we expect that these same variables will be useful for quantifying the fine-scale canopy structure associated with murrelet occupancy throughout the Oregon Coast Range. 


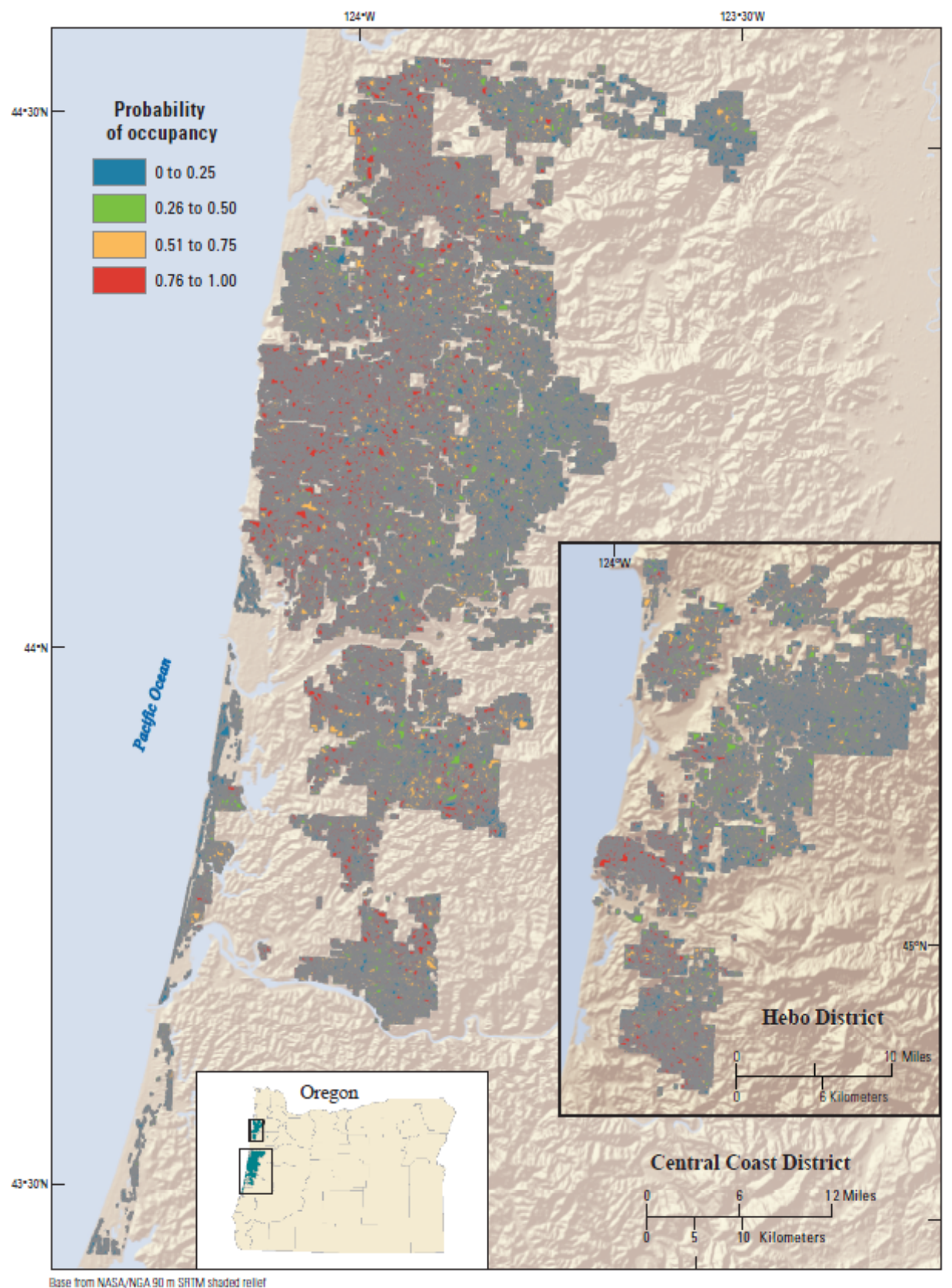

Figure 2. Predicted probability of occupancy for nesting Marbled Murrelets in the Siuslaw National Forest, Oregon, generated from lidar-derived covariates specified by a habitat model developed in the Coos Bay BLM District and transferred to the Siuslaw NF with coefficients derived from local data ("CO_SI model"). 


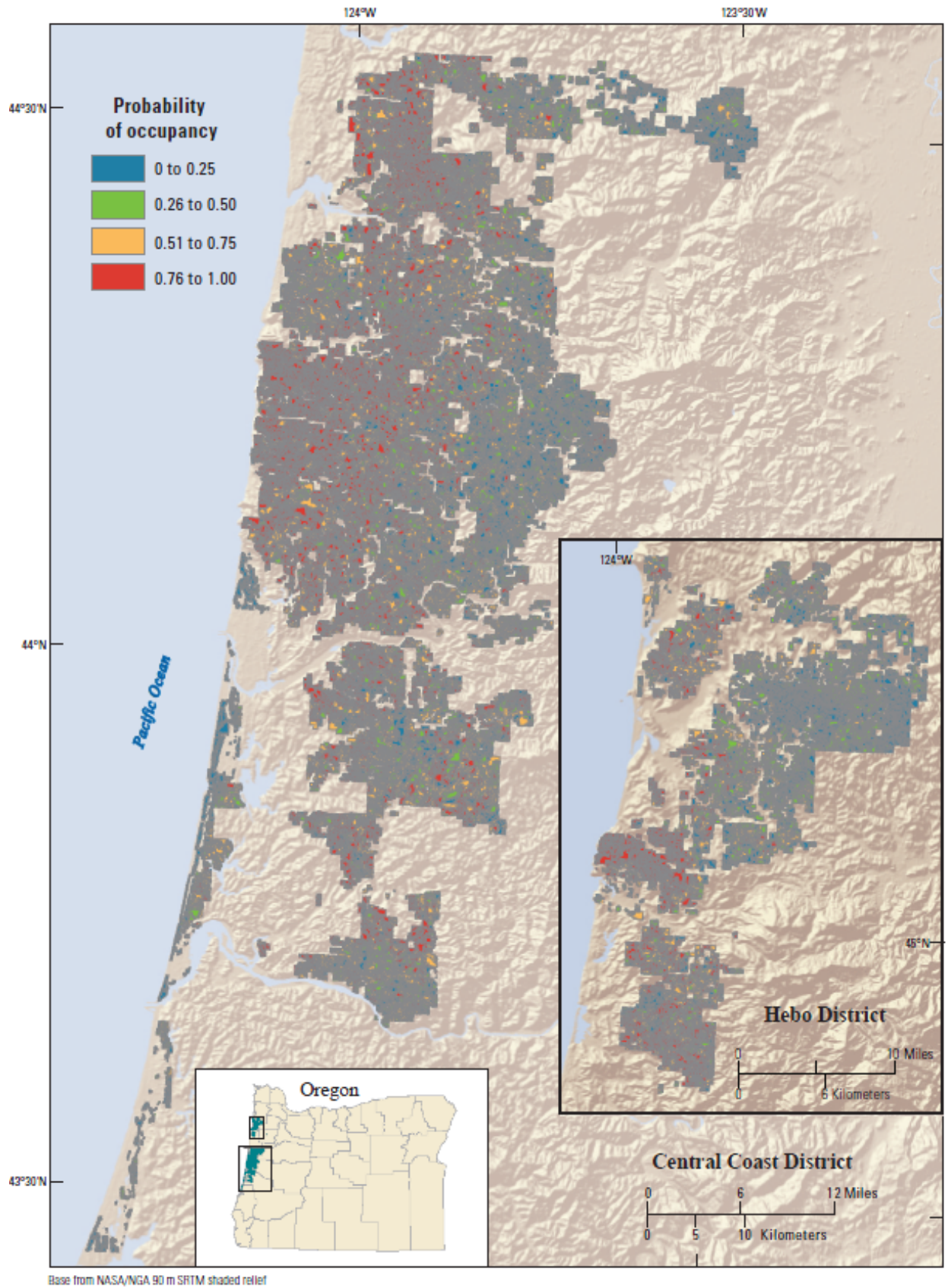

Figure 3. Predicted probability of occupancy for nesting Marbled Murrelets in the Siuslaw National Forest, Oregon, generated from a habitat model trained on locally acquired (Siuslaw NF) lidar-derived variables quantifying forest structure ("SIUSz model”). 


\section{Acknowledgments}

S.K. Nelson provided murrelet survey data. J. Kertis helped obtain GIS vegetation layers for Siuslaw NF. Two anonymous reviewers provided helpful comments and edits that improved the quality of this report.

\section{References Cited}

Ackers, S.H., Davis, R.J., Olsen, K.A., and Dugger, K.M., 2015, The evolution of mapping habitat for northern spotted owls (Strix occidentalis caurina) - A comparison of photo-interpreted, Landsatbased, and lidar-based habitat maps: Remote Sensing of Environment, v. 156, p. 361-373. https://doi.org/10.1016/j.rse.2014.09.025.

Anderson, D.R., 2008, Information Theory and Entropy. In: Model Based Inference in the Life Sciences: A Primer on Evidence. Springer, New York, NY. P. 51-82. https://doi.org/10.1007/978-0387-74075-1 3.

Arnold, T. W. ,2010, Uninformative Parameters and Model Selection Using Akaike's Information Criterion: Journal of Wildlife Management, v. 74, p. 1175-1178. https://doi.org/10.2193/2009-367.

Burnham, K. P. and Anderson, D. R., Eds., 2002, Model selection and multimodel inference: a practical information-theoretic approach. New York, Springer-Verlag.

Chen, J. J., C.-A. Tsai, H. Moon, H. Ahns, J. J. Young, and Chen, C. H., 2006, Decision threshold adjustment in class prediction. SAR and QSAR in Environmental Research 17:337-352. https://doi.org/10.1080/10659360600787700

Davis, R.J., Ohmann, J.L., Kennedy, R.E., Cohen, W.B., Gregory, M.J., Yang, Z., Roberts, H.M., Gray, A.N., and Spies, T.A., 2015, Northwest Forest Plan-the first 20 years (1994-2013)—Status and trends of late-successional and old-growth forests: Portland, Oregon, U.S. Department of Agriculture, Forest Service, Pacific Northwest Research Station, General Technical Report PNWGTR-911, 112 p.

Evans Mack, D., Ritchie, W.P., Nelson, S.K., Kuo-Harrison, E., Harrison, P., and Hamer, T.E., 2003, Methods for surveying Marbled Murrelets in forests - A revised protocol for land management and research: Pacific Seabird Group Technical Publication Number 2, accessed June 27, 2017, at http://www.pacificseabirdgroup.org.

Fielding, A.H., and Bell, J.F., 1997, A review of methods for assessment of prediction errors in conservation presence/absence models: Environmental Conservation, v. 24, no. 1, p. 38-49. https://doi.org/10.1017/S0376892997000088.

Guisan, A., and Thuiller, W., 2005, Predicting species distribution-Offering more than simple habitat models: Ecology Letters, v. 8, no. 9, p. 993-1009, https://doi.org/10.1111/j.14610248.2005.00792.x.

Hagar, J.C., Eskelson, B.N.I., Haggerty, P.K., Nelson, S.K., and Vesely, D.G., 2014, Modeling marbled murrelet (Brachyramphis marmoratus) habitat using LiDAR-derived canopy data: Wildlife Society Bulletin, v. 38, no. 2, p. 237-249, https://doi.org/10.1002/wsb.407.

Hamer, T.E., and Nelson, S.K., 1995, Characteristics of marbled murrelet nest trees and nesting stands, in Ralph, C.J., Hunt, G.L., Jr., Raphael, M.G., and Piatt, J.F., eds., Ecology and conservation of the marbled murrelet: Albany, California, U.S. Department of Agriculture Forest Service General Technical Report PSW-152, p. 69-82.

Hosmer, D.W., and Lemeshow, S., 1980, Goodness of fit tests for the multiple logistic regression model: Communications in Statistics - Theory and Methods, v. 9, no. 10, p. 1043-1069, https://doi.org/10.1080/03610928008827941. 
Johnston, A.N., and Moskal, L.M., 2017, High-resolution habitat modeling with airborne LiDAR for red tree voles: The Journal of Wildlife Management, v. 81, no. 1, p. 58-72, https://doi.org/10.1002/jwmg.21173

Latif, Q.S., Saab, V.A., Hollenbeck, J.P., and Dudley, J.G., 2016, Transferability of habitat suitability models for nesting woodpeckers associated with wildfire: The Condor, v. 118, no. 4, p. 766-790, https://doi.org/10.1650/CONDOR-16-86.1.

Luck, G.W., 2002, The habitat requirements of the Rufous Treecreeper (Climacteris rufa). 2. Validating predictive habitat models: Biological Conservation, v. 105, no. 3, p. 395-403, https://doi.org/10.1016/S0006-3207(01)00223-3.

MacArthur, R.H., and MacArthur, J.W., 1961, On bird species diversity: Ecology, v. 42, no. 3, p. 594-598, https://doi.org/10.2307/1932254.

McGaughey, R.J., 2016, FUSION/LDV—Software for LIDAR data analysis and visualization: U.S. Department of Agriculture.

Nelson, S.K., 1997, Marbled murrelet (Brachyrarnphus marmoratus), account 276 in Poole, A., and Gill, E., eds., The birds of North America online: The Academy of Natural Sciences, Philadelphia, Pennsylvania; and The American Ornithologists Union, Washington, D.C., accessed April 1, 2017, at http://bna.birds.cornell.edu/bna/species/276.

Pearce, J., and Ferrier, S., 2000, Evaluating the predictive performance of habitat models developed using logistic regression: Ecological Modelling, v. 133, no. 3, p. 225-245, https://doi.org/10.1016/S0304-3800(00)00322-7.

Ralph, C.J., Hunt, G.L., Raphael, M.G., and Piatt, J.F., 1995. Ecology and conservation of the marbled murrelet: Albany, California, Pacific Southwest Research Station, Report PSW-GTR-152,, https://doi.org/10.2737/PSW-GTR-152.

U.S. Department of Agriculture, Forest Service and U.S. Department of the Interior, Bureau of Land Management, 1994, Record of decision for amendments to Forest Service and Bureau of Land Management planning documents within the range of the northern spotted owl: U.S. Department of Agriculture and U.S. Department of the Interior, $74 \mathrm{p}$.

U.S. Fish and Wildlife Service, 1997, Recovery plan for the threatened marbled murrelet (Brachyramphus marmoratus) in Washington, Oregon, and California: Portland, Oregon, U.S. Fish and Wildlife Service, $203 \mathrm{p}$.

Vogeler, J.C., Hudak, A.T., Vierling, L.A., and Vierling, K.T., 2013, Lidar-derived canopy architecture predicts Brown Creeper occupancy of two western coniferous forests: The Condor, $\mathrm{v}$. 115 , no. 3 , p. 614-622, https://doi.org/10.1525/cond.2013.110082. 


\section{Appendix 1. Summary of Lidar Collections for Western Oregon}

[Abbreviations: LAS, Lidar Aerial Survey; Lidar, light detection and ranging; USDA/FS, U.S Department of Agriculture Forest Service; UTM, Universal Transverse Mercator]

\begin{tabular}{|llcl|}
\hline Lidar project areas & \multicolumn{1}{c|}{ Acquisition dates } & LAS files (n) & \multicolumn{1}{c|}{ Notes } \\
\hline North Coast & April 21, 2009-August 9, 2009 & 624 & Oregon LiDAR Consortium standards \\
\hline Yambo & March 17, 2010-July 14, 2010 & 505 & Oregon LiDAR Consortium standards \\
\hline Central Coast & September 2, 2011-May 11, 2012 & 693 & Oregon LiDAR Consortium standards \\
\hline Lane & September 7, 2013-October 10, 2014 & 786 & Oregon LiDAR Consortium standards \\
\hline South Coast & July 27 2008-April 9, 2009 & 451 & Oregon LiDAR Consortium standards \\
\hline Yaquina/Elk Creek & July 13, 2005-July 15, 2005 & 114 & $\begin{array}{c}\text { USDA/FS Contract, data projected in } \\
\text { UTM coordinates, reprojected to } \\
\text { Oregon HARN Lambert, data collection } \\
\text { standards same as OLC }\end{array}$ \\
\hline
\end{tabular}




\section{Appendix 2. Summary of Final and Candidate Habitat Models for Marbled Murrelet in the Siuslaw National Forest, Oregon}

\section{Final Model Equations}

COOS Equation (Hagar and others, 2014)

$\mathrm{Y}=-15.416+0.078 *$ allcvabvmn_MAX $+0.048 *$ elev_P99_MAX $+0.068 *$ elev_P10_MAX $+0.142 *$ frstcvabvmd_STD $+1.940 *$ elev_kurt_MIN-0.059* DIS2COAST

COSI Equation

$$
\begin{aligned}
& \mathrm{Y}=-7.7715+0.0086 * \text { allcvabvmn_MAX }+0.1329 * \text { elev_P99_MAX }+0.0219 * \text { elev_P10_MAX - } \\
& 0.0315 * \text { frstcvabvmd_STD }+0.7266 * \text { elev_kurt_MIN-0.1403* DIS2COAST } \\
& \text { SIUSz Equation }
\end{aligned}
$$

$$
\begin{gathered}
\mathrm{Y}=0.1518-1.2689 * \mathrm{DIS} 2 \mathrm{COASTz}+1.273 * \mathrm{CRR} \text { _MEANz }-0.2909 * \mathrm{STR} 2 \text { _STDz }+ \\
1.3637 * \text { elev_skew_MEANz }+1.5884 * \text { elev_P99_MAXz }
\end{gathered}
$$

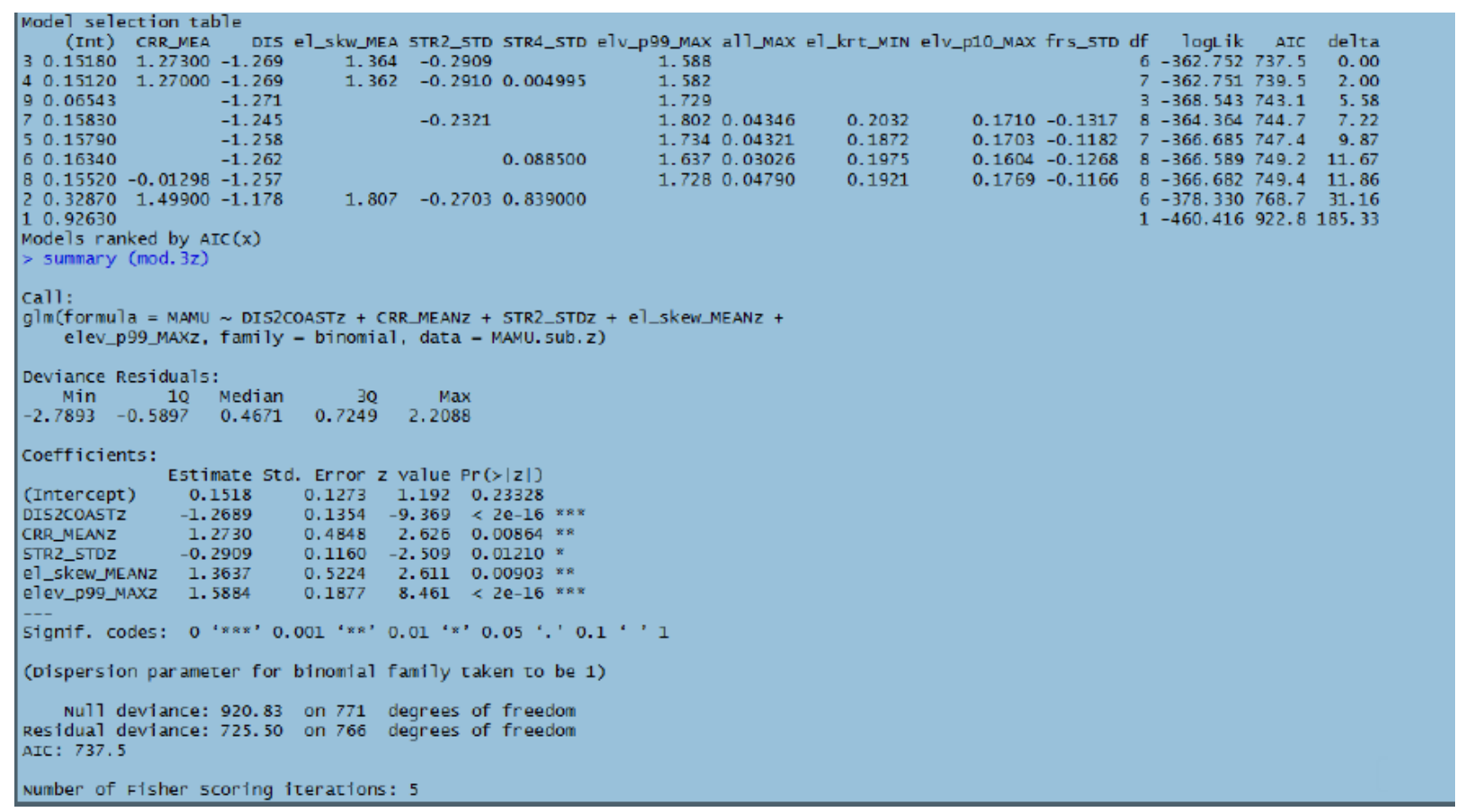




\section{Appendix 3. Comparison of Distributions of Variables Used to Develop Marbled Murrelet Habitat Model between Coos Bay Area (model development location) and Siuslaw National Forest (model application location), Oregon}

Boxplots show medians (center horizontal bar), interquartile range (upper and lower horizontal bars), and minimum and maximum values (extent of vertical bars), with outliers shown as distinct dots.
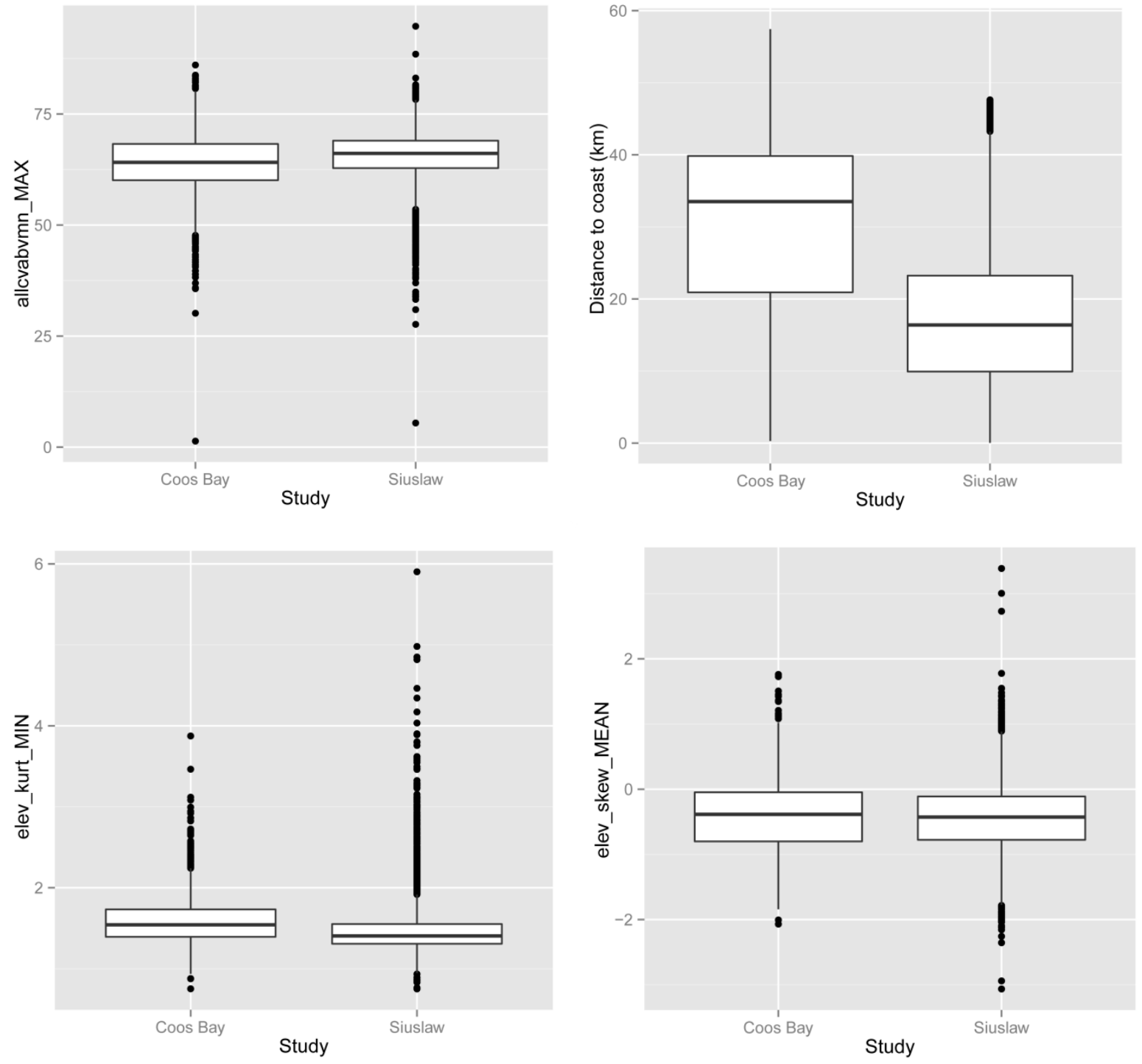

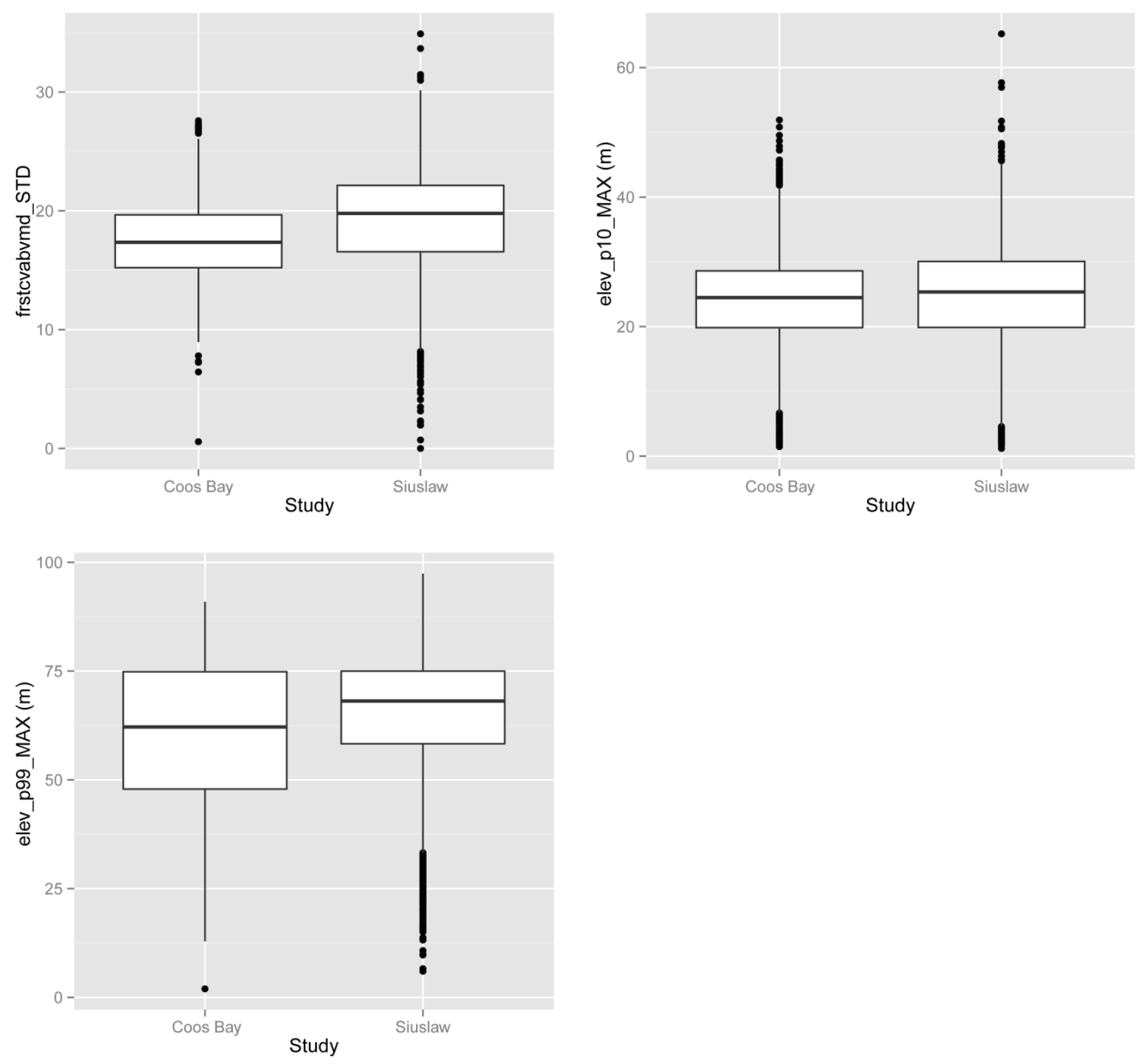

Publishing support provided by the U.S. Geological Survey Science Publishing Network, Tacoma Publishing Service Center

For more information concerning the research in this report, contact the Director, Forest and Rangeland Ecosystem Science Center U.S. Geological Survey 777 NW 9th St., Suite 400

Corvallis, Oregon 97330

https://fresc.usgs.gov/ 


\section{$\frac{\mathbb{2}}{3}$}

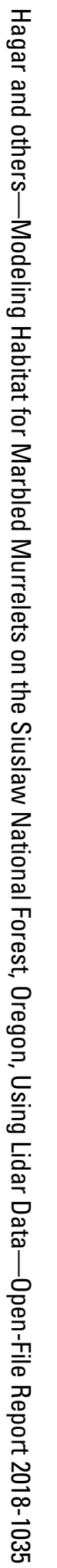

